UNITED STATES DEPARTMENT OF THE INTERIOR Harold L. Ickes, Secretary

GEOLOGICAL SURVEY

W. C. Mendenhall, Director

\title{
Bulletin 936-I
}

\section{NICKEL-COPPER DEPOSITS ON THE WEST COAST OF CHICHAGOF ISLAND, ALASKA}

\author{
BY \\ WILLIAM T. PECORA
}

Strategic Minerals Investigations, 1942

(Pages 221-243)

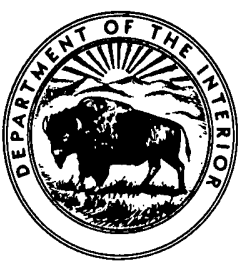

UNITED STATES

GOVERNMENT PRINTING OFFICE

WASHINGTON : 1942 



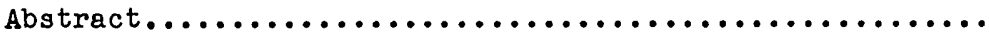

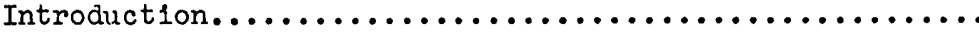
Location and accessibility of the deposits..........

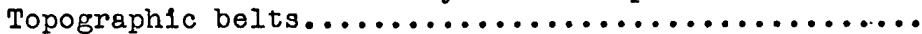

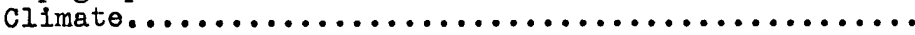

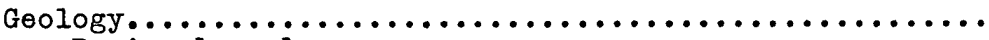

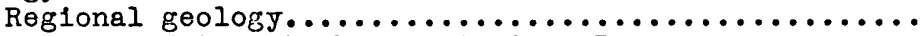

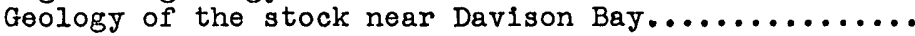

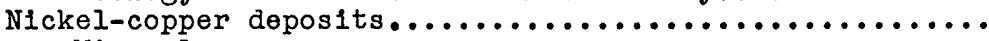

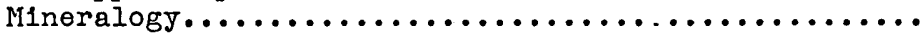

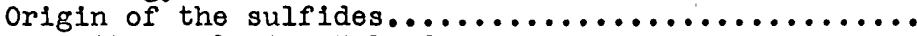

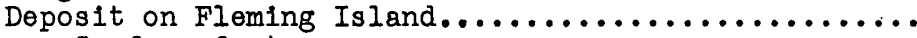

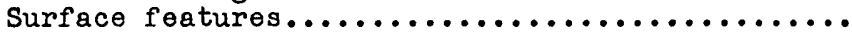

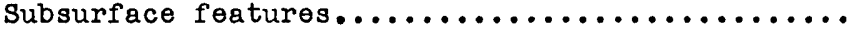

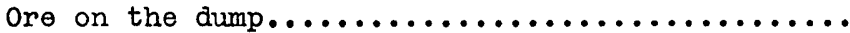

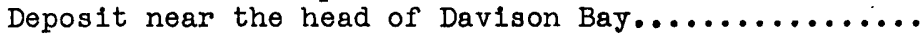

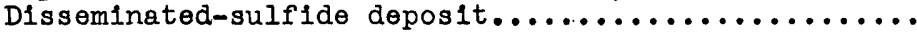

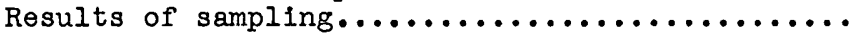

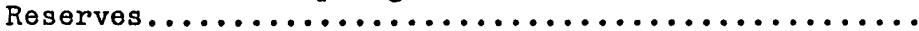

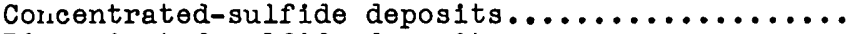

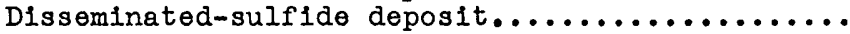

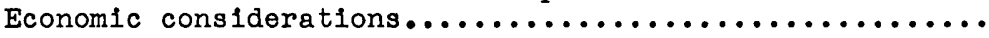

\section{ILLUSTRATIONS}

Page

Plate 36. Geolog1c map of the stock near Davison Bay,

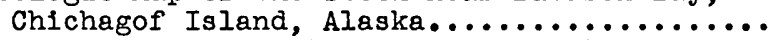

37. Map showing prospect pits and tentative surface outline of the disseminated-sulfide

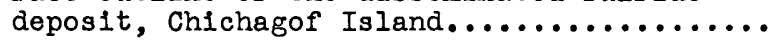

F1gure 22. Index map of southeastern Alaska showing location of the nickel-copper deposits on the west coast of Chichagof Island............

23. Generalized geologic map of a part of western

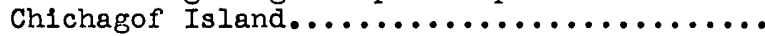

24. Sketch map showing outcrop of concentratedsulfide deposit near the shaft on Fleming

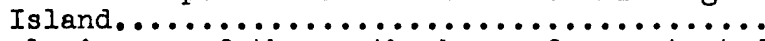

25. Geologic map of the south shore of a protected cove near the head of Davison Bay...........

26. Sketch map of outcrop of concentrated-sulfide deposit in norite near the head of Davison

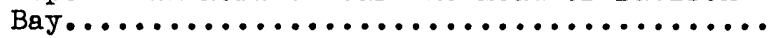




\section{TABLES}

Page

Table 16. Weather records for Kimshan Cove, Alaska, from August 1940 to September $1941 . \ldots \ldots \ldots \ldots \ldots$

17. Analytical data and ratios of nickel to copper and of sulfur to nickel plus copper, in samples from the nickel-copper deposits on the

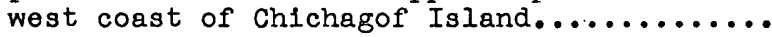

IV 


\title{
NICKEL-COPPER DEPOSITS ON THE WEST COAST
}

\author{
OF CHICHAGOF ISLAND, ALASKA
}

\author{
By William T. Pecora
}

ABSTRACT

On the west coast of Chichagof Island, southeastern Alaska, are three nickel-copper deposits that consist of norite containIng the sulfide minerals pyrrhotite, pentlandite, and chalcopyrite. The deposits are within less than a mile of each other and are, by water, $160 \mathrm{mlles}$ southwest of Juneau and $70 \mathrm{mlles}$ northwest of sitka. The norite is part of a stock, about 5 square miles of which is above sea level. Other rocks of the stock are amphibolite, amphibolitic norite, gabbro, diorite, quartz diorite, monzonite, granite, pegmatites, quartz veins, and schist inclusions. The stock is intrusive into a Lower Cretaceous (?) graywacke formation and an Upper Triassic (?) greenstone formation, both of which are now metamorphosed to schist.

The deposits are of two kinds: (1) A disseminated-sulfide deposit, in which the sulfide minerals are distributed throughout the mass of the norite, and (2) concentrated-sulfide deposits, in which the sulfide minerals are in distinct podlike masses of sulfide-rich norite. The deposits of type 2 are coarser-grained, smaller, and higher in nickel and copper than those of type 1.

Two of the three deposits described are of the concentratedsulfide variety. One of these, the Fleming Island deposit, has been partly developed by means of a 175-foot shaft, now flooded, by 71 feet of underground openings on a 75-foot level, of which 37 feet are reported to be in ore, and by 85 feet of openings on the 175-foot level, of which 14 feet are reported to be in ore. A sample representing 400 square feet, or half the surface outcrop, contains 0.58 percent of nickel and 1.15 percent of copper. It is reported that 37 feet of sulfide ore on the 75-foot level has an average content of 3.42 percent of nickel and 1.15 percent of copper, and that a half-ton sample from the 175-foot level contained 2.41 percent of nickel and 1.00 percent of copper. If the ore body is continuous between the surface and the 175-foot level, the deposit is a steeply dipping ore shoot which contains more than 10,000 tons of ore. The ore contains possibly 2 percent of nickel and 1 percent of copper.

A second outcrop of concentrated sulfides is near the water's edge, about 3,000 feet southeast of the one mentioned above. Its area is about 500 square feet, and the material exposed resembles that of the Fleming Island deposit; though the samples taken, which were hardly adequate in number, indicate that 1 t is of somewhat lower grade. No subsurface exploration has been done here. 
The deposit composed of norite with disseminated sulfides is exposed about 1,000 feet southeast of the second deposit of concentrated sulfides. It probably contains a few mililon tons of low-grade material with perhaps 0.2 percent of nickel and 0.1 percent of copper.

\section{INTRODUCTION}

The occurrence of nickel on the west coast of Chichagof Island was first reported in 1911 by S. H. P. Vevelstad. In 1917, a 175-foot shaft was sunk by the Alaska Nickel Co. on Fleming Island, near a prominent outcrop containing abundant sulfide minerals. Sulfides were encountered on the 75-foot and 175-foot levels. A second outcrop showing abundant sulfides and similar to that on Fleming Island is also known but has not yet been developed. In the summer of 1941, a few acres underlain principally by rock contalning disseminated sulfides were discovered and explored by means of 45 pits and trenches.

The writer did the field work on which this report is based between June 15 and September 4, 1941, with the assistance of John B. Lyons and Darwin L. Rossman. H. Lester Rink served as cook. John C. Reed visited the party several times during the season.

The Hirst-Chichagof Mining Co., and especially Paul M. Sorensen, its general superintendent, extended many courtesies during the field season. Territorial and Federal agencies in Juneau also gave help of various kinds. A report by J. C. Rogers on the underground workings on Fleming Island was made available to the Geological Survey by the International Nickel Co. Harold E. Mattson, in charge of the United States Weather Bureau Station at Kimshan Cove, provided records of rainfall and temperature.

\section{Location and accessibility of the deposits}

The nickel-copper deposits described in this report are on the west coast of Chichagof Island, one of the large islands of 
the Alexander Archipelago of southeastern Alaska. By water they are about 160 miles southwest of Juneau, about 70 miles northwest of Sitka, and about 12 miles northwest of Kimshan Cove, a

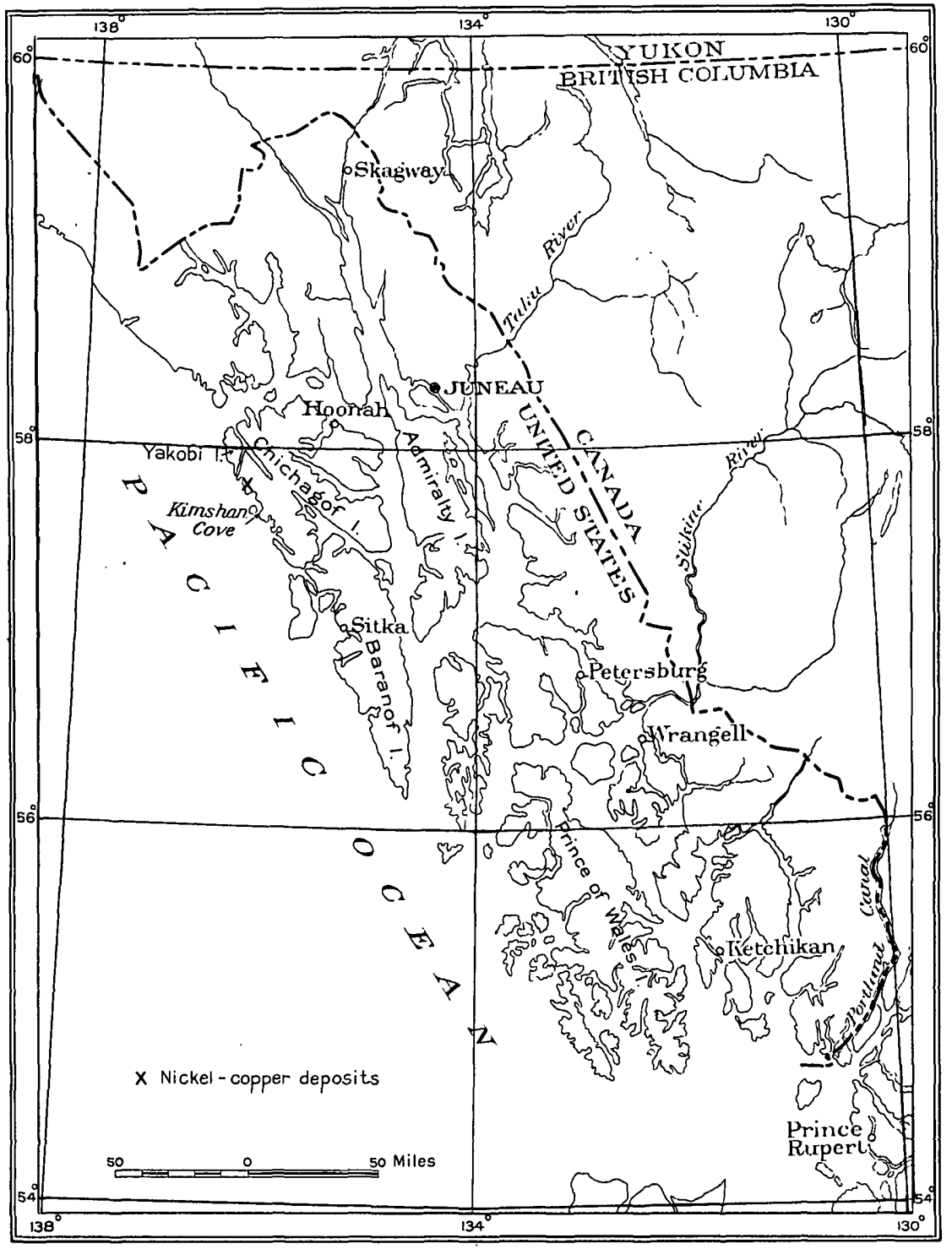

Pigure 22.--Index nap of southeastern Alaske showing location of the nlckel-copper deposits on the west cosst of Chlchagof I sland.

small mining comminity and the nearest post office (fig. 22). One deposit is on the north tip of Fleming Island, a small 1sland between Davison Bay and Mirror Harbor (see pl. 36), and 
two other deposits, less than a mile southeast, are on Chichagof Island.

The west coast of Chichagof Island in the vicinity of the deposits is so studded with small islands and reefs that it cannot be reached by large boats. I/ small fishing boats and motor launches, however, have a protected anchorage in Mirror Harbor and West Arm. Alrplane service is maintained almost daily from Juneau to Sitka and Kimshan Cove, and planes can be chartered for landing almost anywhere on the nearby land-locked waters. A well-marked foot-trail, built and maintained by the United States Forest Service, extends from Dry Passage to White Sulphur Springs, at the head of Bertha Bay, and a branch of this trail leads to the West Arm anchorage.

\section{Topographic belts}

Two conspicuous topographic belts characterize the part of Chichagof Island shown in figure 23: A coastal belt which, near Davison Bay, has a maximum relief of about 150 feet and a maximum width of about 4 miles; and a mountainous belt which rises abruptly east of the coastal belt to altitudes of a few thousand feet. The nickel-copper deposits lie entirely in the coastal belt.

Many rapid streams drain the mountainous area and, with much gentler gradients, cross the coastal belt. Falls Creek, which drains Lake Morris, is a possible source of water power, and some of the other streams of the vicinity also may be suitable for this purpose.

Timber is locally plentiful both in the mountains and along the coast, but very little that can be used for mining purposes is readily accessible from the water. The Hirst-Chichagof Mining Co. at present uses logs rafted from Baranof Island to its mill at Kimshan Cove.

\footnotetext{
1/ J. S. Cosst and Goodot1c Surveg chart 8258 mas be used for navigation in this area.
} 
Rock outcrops in the coastal belt are largely confined to sea cliffs and the part of the shores of inlets, channels, and sloughs that are exposed between high and low tide. The surface of this belt is characterized by heavy vegetation and swampy areas called muskeg; the cover of soll and vegetative debris is commonly between 2 and 5 feet thick. Between the soll and bedrock lies a thin veneer of volcanic ash, which weathers to an impervious clay that prevents adequate drainage of many swampy areas.

\section{Climate}

The deposits are in a region of high precipitation, most of which falls as rain. Rainfall and temperature have been recorded at Kimshan Cove since August 1940, and the ava1lable records for this station are given in table 16 .

Table 16.--Weather records for Kimshan Cove, Alaska, from August 1940 to September 1941. [Courtesy of the U. S. Weather Bureau]

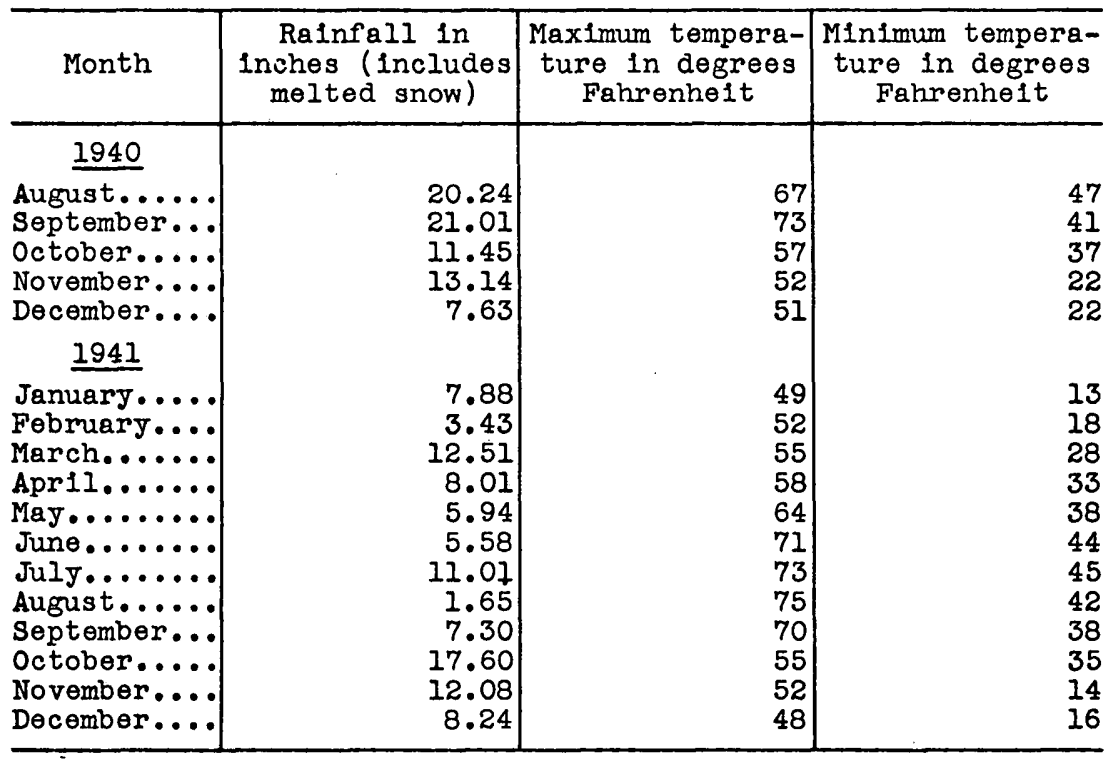

$4664420-42-2$ 


\section{GEOLOGY}

\section{Regional geology}

Descriptions of the geology and mineral resources of parts

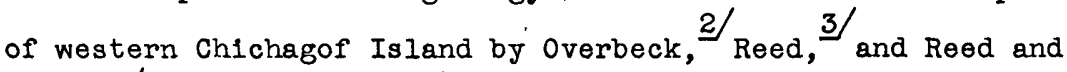
Coats, 4 have been published.

In the area included in figure 23, northwestward-trending rocks, principally graywacke and greenstone, are intruded by three large stocks of igneous rocks. Both the graywacke and the greenstone in the vicinity of the stocks are metamorphosed to schist. The age of the graywacke may be Lower Cretaceous and that of the greenstone may be Upper Triassic.

The intrusive stock near Davison Bay, described in a followIng section, contains the nickel-copper deposits. A second stock, in the vicinity of Lost Cove and Islas Bay, is made up largely of dioritic rocks similar to those in the stock near Davison Bay; but reconnalssance examination of the second stock has falled to disclose any nickel-copper deposits. The third stock, near Lakes Elfendahl and Morris, is composed essentially of granite.

Reed and Dorr $5 /$ report that a large stock on Yakob1 Island (see fig. 22) contains sulfide-bearing norite. Additional areas of sulfide-bearing rocks may yet be disclosed by further examination of the western part of Yakob1 Island,

2/ Ororbeck, R. M., Geology and nineral resources of the west coast of Chlchagof Island, Mlaska: 0. 8. Geol. Surveg Bull. 692, pp. 91-136, 1919. 3/ Beed, J. C., Prellininary report on the ore deposits of the Chichagof min1ng dietrict, Liaska: Am. Inat. Min. Kot. Toch. Pab. Mo. 1051, 20 pp.. 1939.

4/ Beed, J. C.. and Coats, R. B., Geologs and ore deposits of the Chichegof mining district: 0 . S. Oool. Surver Ball. 929, 147 pp., 1942.

5/ Boed, J. C., and Dorr, J. V. H., 2d, IIckol doposits of Bohemia Basin

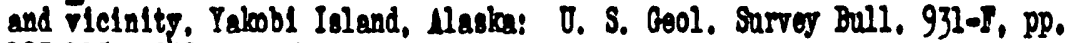
105-138, 1942. 


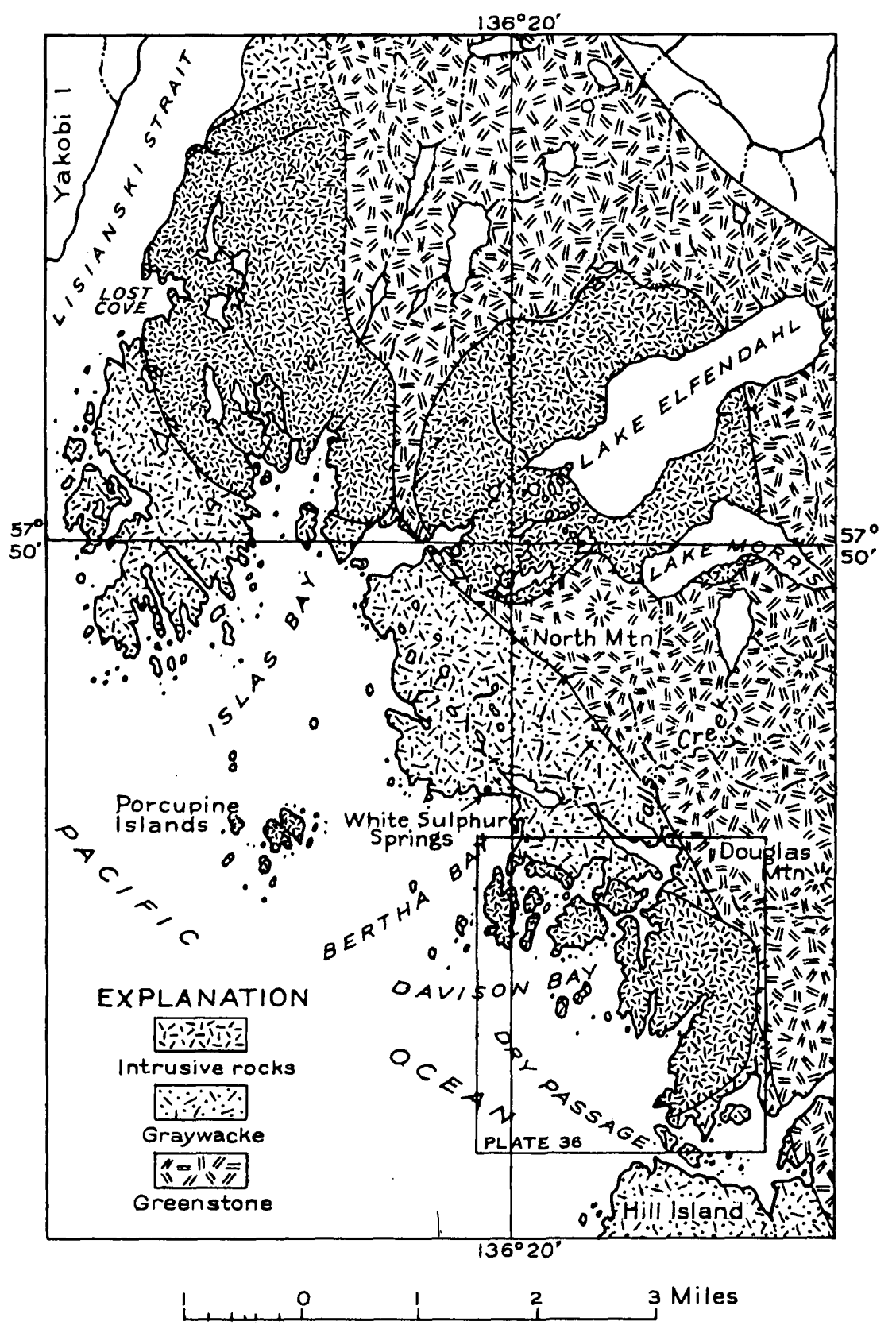

Tigure 23.--Gonerallsod goologie map of a part of wostern Chichagof Ialand. 


\section{Geology of the stock near Davison Bay}

Near Davison Bay a composite stock of igneous rocks intrudes the metamorphosed rocks. (See pl. 36.) The metamorphic rocks are follated and are made up of such minerals as biotite, garnet, amphibole, chlorite, andalusite, staurolite, comandum, quartz, and feldspar.

About 5 square miles of the stock is above sea level, but a larger area probably is submerged off shore. The rocks composing the stock include amphibolite, norite, gabbro, diorite and quartz diorite, quartz syenite, quartz monzonite, granite, pegmatites, quartz veins, and schist inclusions. The amphibolite, norite, and gabbro are collectively mapped on plate 36 as the norite group, and the remainder as the diorite group. Schist inclusions are present in the members of both groups, being particularly abundant in those of the diorite group that are rich In both quartz and biotite. Small scattered bodies of rocks of each group are common in the rocks of the other group. Some rocks of the norite group, even where present as small bodies within rocks of the diorite group, have an indistinct layering that is roughly accordant with the cleavage of the schists surrounding the stock.

Sulfides occur in many rocks of the stock but are most abundant in those of the norite group; deposits of possible economic Importance are therefore most likely to be found in the areas represented in plate 36 as underlain principally by norite.

The writer believes that the original magma of the stock was intruded into older rocks by forceful infection and assimilation, and that the amphibolite, norite, gabbro, and dorite represent products of differentiation during crystalization of the magma. The quartz-biotite granitic rocks wero probably formed in part by assimilation of inclusions in residual practions of the crystallizing magma and in part by wholesale replacement and recrys- 


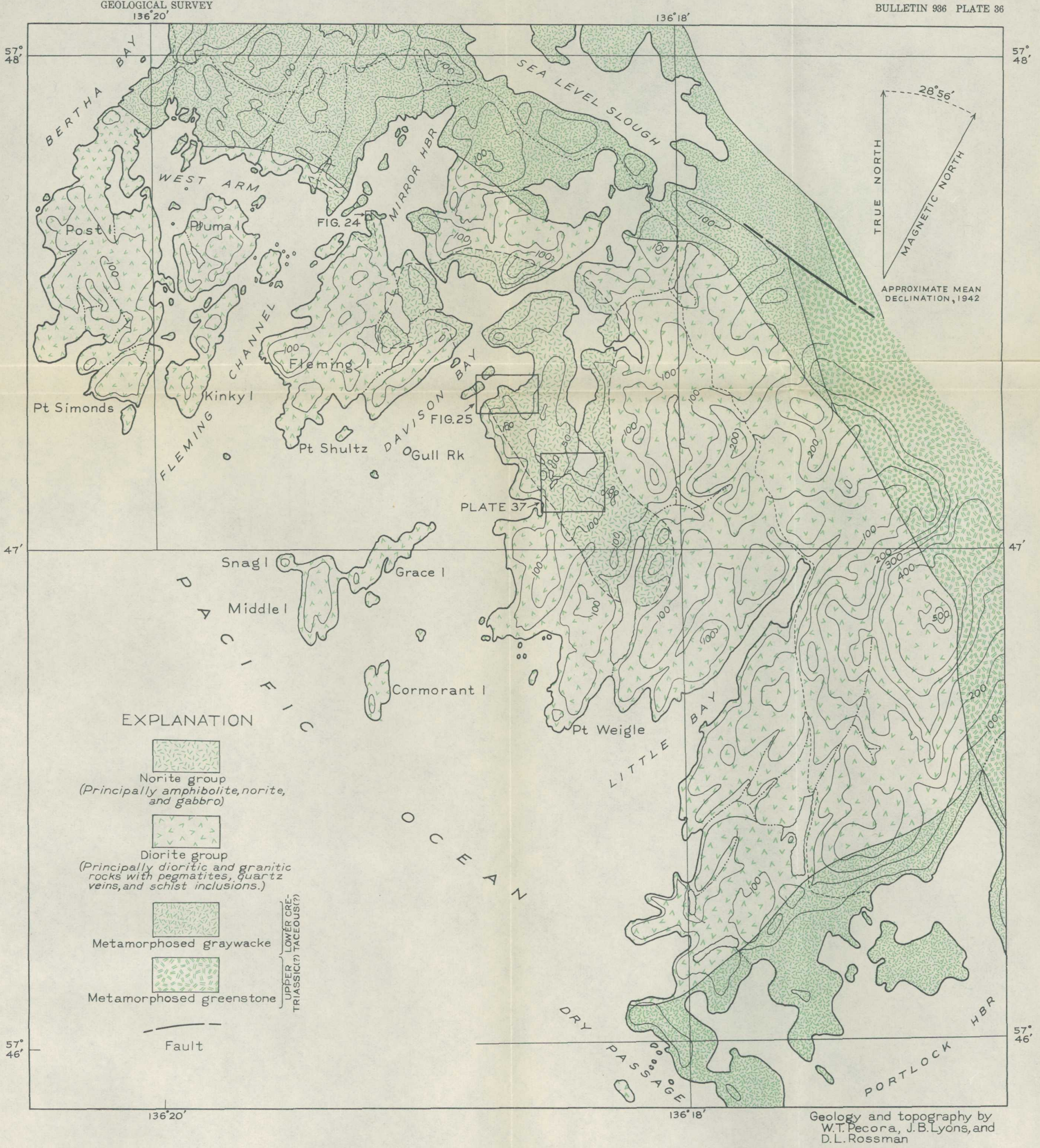


tallization of graywacke or greenstone by fluids emanating from the magma.

\section{NICKEL-COPPER DEPOSITS}

- The nickel-copper deposits consist of norite containing the sulfides pyrrhotite, chalcopyrite, and pentlandite. Both concentrated-sulfide and disseminated-sulfide deposits are recognized, the former having a higher nickel and copper content but a smaller volume than the latter.

of the two prominent outcrops of the concentrated-sulfide deposits, one on Fleming Island has been partly developed; the second, near the head of Davison Bay, remains undeveloped. The outcrops resemble each other in mineralogy and in their geologic relations, and each probably represents a well-defined ore body.

A tract of several acres underlain in part by sulfide-bearIng rock was discovered and partly explored on the surface by the claim owners in the summer of 1941. Of this tract, 3 acres (see p1. 37) is considered by the writer to be underlain by a disseminated-sulfide deposit.

\section{Mineralogy}

Kerr $6 /$ has described the mineralogy of several specimens of ore from Chichagof Island. The ore minerals pentlandite $((\mathrm{Fe}, \mathrm{N1}) \mathrm{S})$ and chalcopyrite $\left(\mathrm{CuFeS}_{2}\right)$ are here intimately assoc1ated with pyrrhotite $\left(\mathrm{Fe}_{\mathrm{n}} \mathrm{S}_{\mathrm{n}+1}\right)$. The gangue minerals consist chlefly of the silfcates pyroxene, plagloclase feldspar, and amphibole. The sulfide minerals were formed later than the silicates, and the proportion of the combined sulfides to the silicates, as well as of the sulfides to one another, varies widely. The concentrated-sulfide deposits differ mineralogically from the disseminated-sulfide deposit in having more

6) Korr, P. 2., A magmat lc sulphide ore from Ohlchugof I sland, Alaska: Icon. Coolog. ro1. 19. pp. 369-376, 1924.

$4664420-42-3$ 
abundant and coarser-grained sulfides, more chalcopyrite relative to other sulfides, and coarser-grained pyroxene.

\section{Origin of the sulfides}

The sulfide minerals appear to be magmatic and to have been the last minerals of the norite to crystallize. The disseminated-sulfide deposit may be the result of normal crystallization of a sulfide-rich noritic magma, whereas the concentratedsulfide deposits, with their coarser grair and higher nickel and copper content, may be pegmatitic facies formed by the fractionation of a similar sulfide-rich noritic magma.

\section{Deposit on Fleming Island}

Surface features.--Sulfide-rich norite crops out on the northerm tip of Fleming Island (see pl. 36), near the water's edge and a few feet west of the shaft. The outcrop, as shown in figure 24, measures 20 feet by 40 feet and is readily distinguished from the surrounding norite poor in sulfides. Soll, vegetation, and dump material conceal the bedrock near the shaft.

The outcrop is near the eastern border of an area, 1,200 feet long and 300 feet in maximum width (see pl. 36), underlain by rocks of the norite group. On the east, this area is separated from the blotite-quartz schist of the graywacke formation by rocks of the diorite group. West of the shaft, thin-layered amphibolite and norite striking northwest and dipping steeply southwest form the western part of the lens-shaped area and separate 1t from rocks of the diorite group.

The deposit is characterized by small podlike masses of abundant sulfide minerals. The largest pod seen was 4 inches by 4 inches by 8 inches. The sulfide minerals are commonly coarsegrained and friabl2, and they enclose coarse crystals of pyroxene and plagloclase. The largest pyroxene crystals are half an inch across and $I$ inch long, being conspicuously larger than 
those in the norite poor in sulfides. Some crystals are bent, curved, or broken, and cracks, pits, and 1rregularities in them are fllled with sulfides.

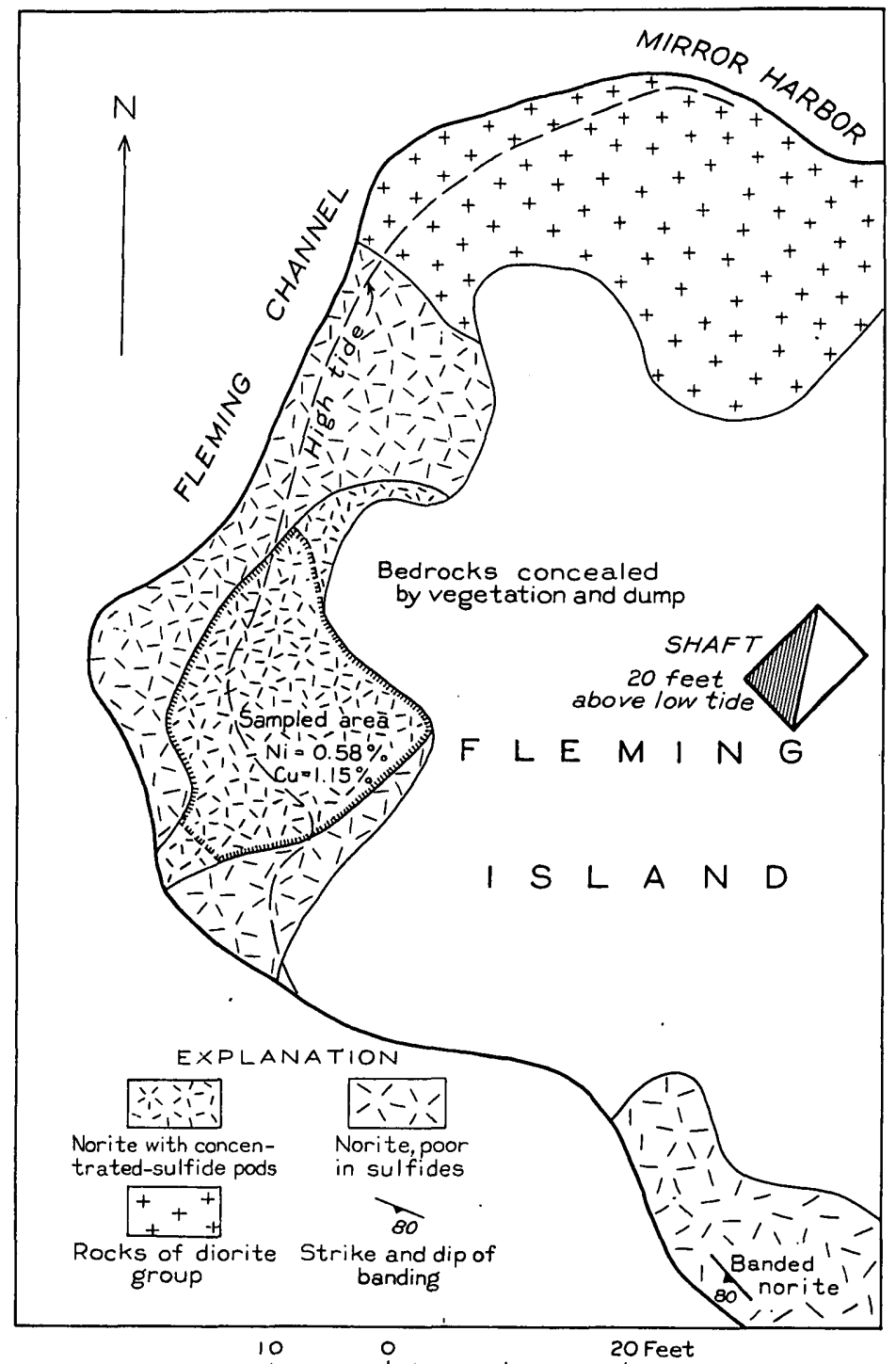

Figure 24. - Sksetch map showing outcrop of concentrated-mulfide doposit near the shaft on Fering Island.

A sample made up of chips collected at l-foot intervals represents about 400 square feet of the surface rock. Despite an endeavor to obtain material as little weathered as possible by first breaking away a surface layer of rock, the sample 
contained some weathered rock. An analysis showed 0.58 percent of nickel, 1.15 percent of copper, and 4.84 percent of sulfur.

Subsurface features.--A few feet east of the outcrop a 175foot shaft has been sunk in hornblende gabbro and hornblende diorite, and sulfide minerals were encountered on the 75-foot and 175-foot levels northwest of the shaft. The water in the flooded shaft is about 10 feet above sea level, and its level does not perceptibly change in response to the dally rise and fall of the tides in nearby Fleming Channel; but a fluctuation of about 3 feet in response to rainy and dry spells was recorded during the summer of 1941.

The information that follows was gleaned from the published reports of Overbeck 7 and Buddington, $8 /$ from field notes of Overbeck on file in the Geological Survey, and from a report prepared in 1917 by J. C. Rogers for the International Nickel Co.

On the 75-foot level there is a 62-foot drift northwest of the shaft, with a 5-foot crosscut near the end, and a 4-foot drift southeast of the shaft. The southeast drift and the first 30 feet of the northwest drift are in barren hornblende gabbro. The remaining 32 feet of the northwest drift and its crosscut are in sulfide-rich norite. Concerning the contact of barren rock and ore, Overbeck / writes: "The contact between the barren rock and the ore-bearing portion appears to be an irregular 11ne. There is rather a rapid transition from barren rock to rock in which there are a few disseminated sulphides, and then to massive ore. The change does not appear to occur progressively but irregularly * * *."

It is reported by Mr. Rogers that the material exposed in the 37 feet of workings in ore on the 75-foot level averages 3.42 percent of nickel and 1.58 percent of copper. Samples

I/ Orerbeck, R. H., op. c1t.. pp. 125-134.

8f Buddington, A. F. Mineral Investigations in southeastem Alaska:

U. S. Gool. Survey bull. 773, pp. 95-98, 1923.

2/ Orerbeck, R. u.. op. c1t.. p. 126. 
4 to 11 in table 17 are the reported analyses of eight samples from the 75-foot level taken by Mr. Rogers in 1917.

Concerning the 175-foot level, 14 feet of which is reported to be in ore, Mr. Rogers writes:

The 175-foot level has 51 feet of main drift, 15 feet of drift southeast and 14 feet of drift northwest, giving a total of 80 feet $10 / * *$ *. The character of the rock here is different than on the 75-foot level, the northwest and southeast drifts being in a brecclated mass between two slips or shear zones. Massive ore is adjacent to slips but the sheared portion appears to be recemented and of a secondary nature * * *. A 1,000 pound shipment * * gave an assay of Cu $1.00, \mathrm{N1} 2.41$, or CuNi 3.41 for ore from this drift.

Five analyses of samples of massive ore from the 175-foot level also reported by Mr. Rogers (samples 13-17, table 17) indicate that the ore on this level contains less nickel and copper than the ore on the 75-foot level.

Ore on the dump.--The broken material on the dump west of the shaft is estimated to weigh about 50 tons and consists of partly oxidized sulfide-rich material, and of norite, diorite, and gabbro. Ten specimens of the sulfide-rich material, weighing in all about 50 pounds, were collected at random from the dump and broken up, and a sample welghing about 3 pounds was made up from the least oxidized fragments of each specimen. An analysis shows (sample 1, table 17): 2.99 percent of nickel, 2.05 percent of copper, and 23.15 percent of sulfur.

The source of the material is not known, as it may have come from either the 75-foot or 175-foot level. In either case, the sample represents only a small amount of the sulfide pods originally enclosed in norite.

\section{Deposit near the head of Davison Bay}

Norite, including sulfide-bearing and amphibolitic varieties and associated with gabbro-diorite and pegmatites, crops out

10/ Xr. Rogers does not mention the direction of the main drift, nor whether the 15-foot and 14-foot drifts were driven from the shaft or from the end of the 51-foot main drift. 
along the shore of a protected cove near the head of Davison Bay and on the small 1slands and reefs that separate the cove from the bay. At locality $A$ in figure 25, a conspicuous outcrop of

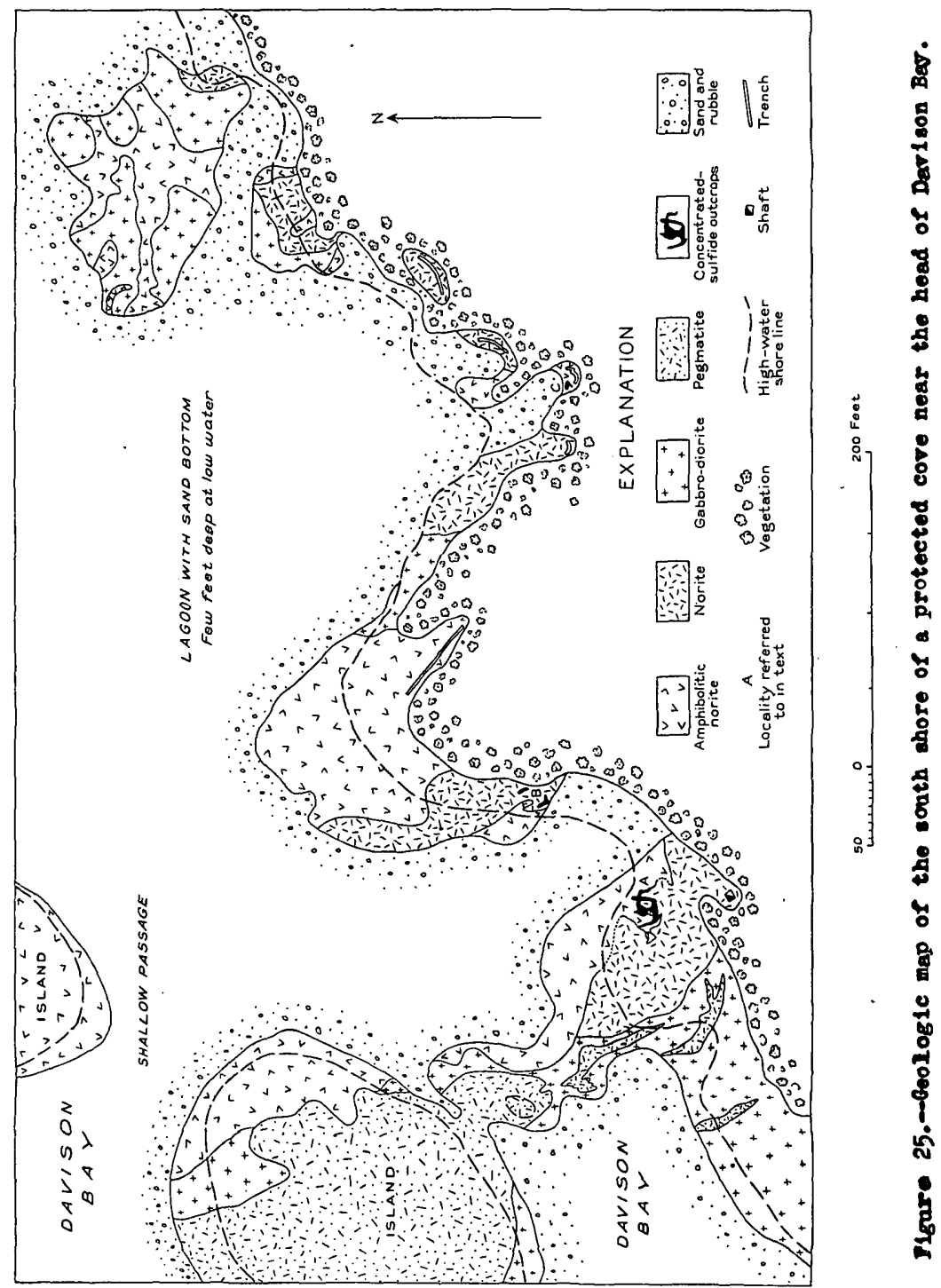

concentrated sulfides projects a few feet above the norite enclosing 1t. Two other deposits of concentrated sulfides crop out at localities B and C of figure 25. 
The outcrop at locality $A$, which is about 3,000 feet southeast of the one on Fleming Island, covers about 500 square feet. The deposit, which does not include all the area (see fig. 26), has irregular contacts against the host rocks. In this outcrop the sulfide pods are larger than in the outcrop on Fleming Island, but the mineral composition and the podlike form of the sulfide masses in the two outcrops are very simllar. Twenty-

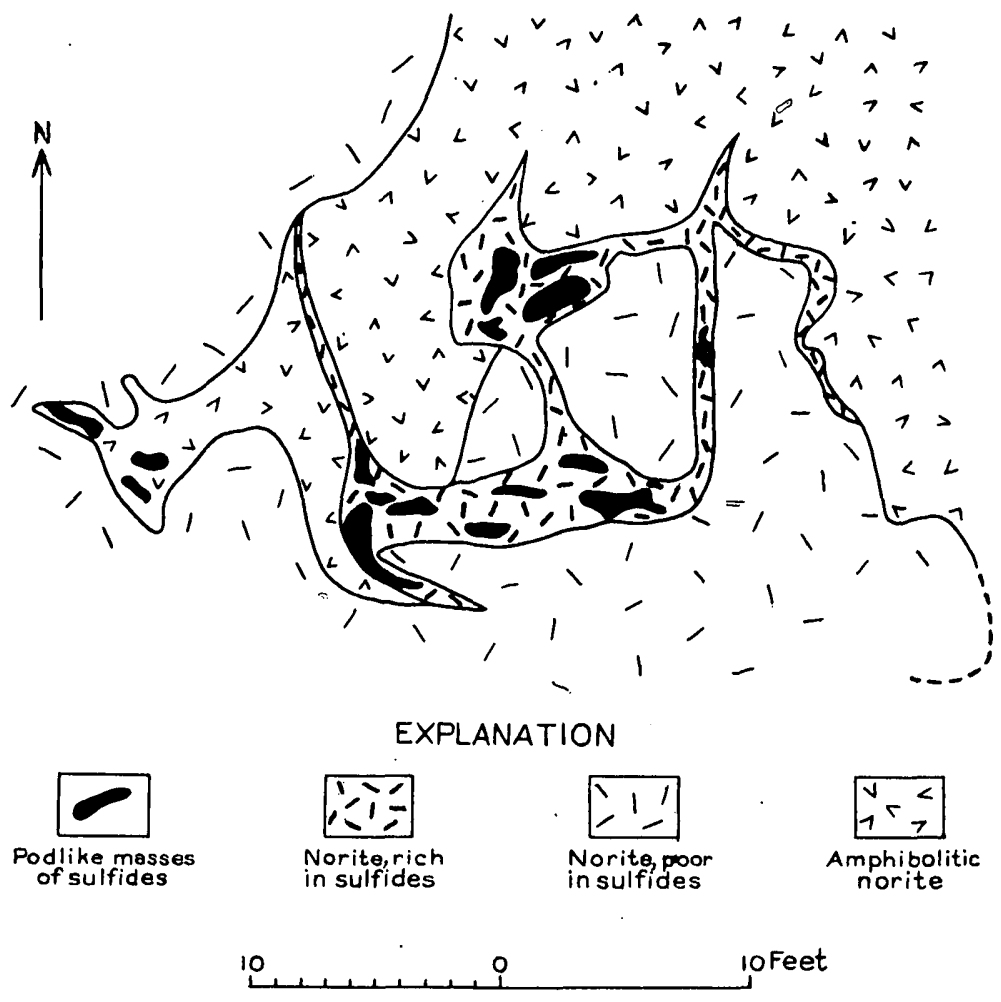

Figure 26. - Skcotch map of outcrop of concentrated-sulfide deposit in norite near the head of Darleon Bas. Outcrop A of flgure 25.

three specimens of sulfide pods, estimated as welghing a total of 300 pounds, were broken up, and pleces from near the center of each specimen were collected to make a representative sample. The sample (sample 2, table 17) was found to contain 1.50 percent of nickel, 0.99 percent of copper, and 15.00 percent of sulfur. The N1:Cu ratio is computed to be $3: 2$, the same as that computed from the analysis of the concentrated-sulfide pods 
collected at the dump near the shaft on Fleming Island (sample 1 , table 17). As shown in figure 26, the sulfide pods make up only a small percentage of the deposit. The nearby shaft has been sunk only a few feet into bedrock.

At localities $B$ and $C$ nearby, the concentrated sulfides exposed are in rock that in most places contains disseminated sulfides. Five pits cut into the side of the hill east of locality A expose crumbly norite veined by dikelets of quartzblotite-feldspar pegmatite. The hills to the south and southeast are less than 150 feet high and are almost covered with vegetation, but norite with disseminated sulfides is exposed on them in a few places.

\section{Disseminated-sulfide deposit}

About 4,000 feet southeast of the Fleming Island shaft and 1,000 feet southeast of the sulfide-rich outcrop near the head of Davison Bay, a tract of several acres is underlain principally by rocks containing disseminated sulfides. During the summer of 1941, 45 pits were dug by workers for the clalm-owners in an attempt to explore the bedrock concealed by the vegetation and so1l. (See pl. 37.)

The more abundant rocks exposed in the pits are amphibolite, norite, and gabbro. Less abundant rocks include diorite, pegmatites, and metamorphosed graywicke inclusions. The rock richest in sulfides is norite, and a coarse-grained variety contains a larger proportion of sulfides than a fine-grained one. The amphibolite is closely associated with the norite, and the presence of one is a reliable indication of the proximity of the other. Although sulfide minerals are visible in much of the amphibolite, the nickel and copper content (see table 17) of the rock, as shown by analyses of two samples from the disseminatedsulfide deposit and a third collected nearby, is very low (nickel, 0.03, 0.02, and 0.02 percent; copper, $0.03,0.01,0.02$ 


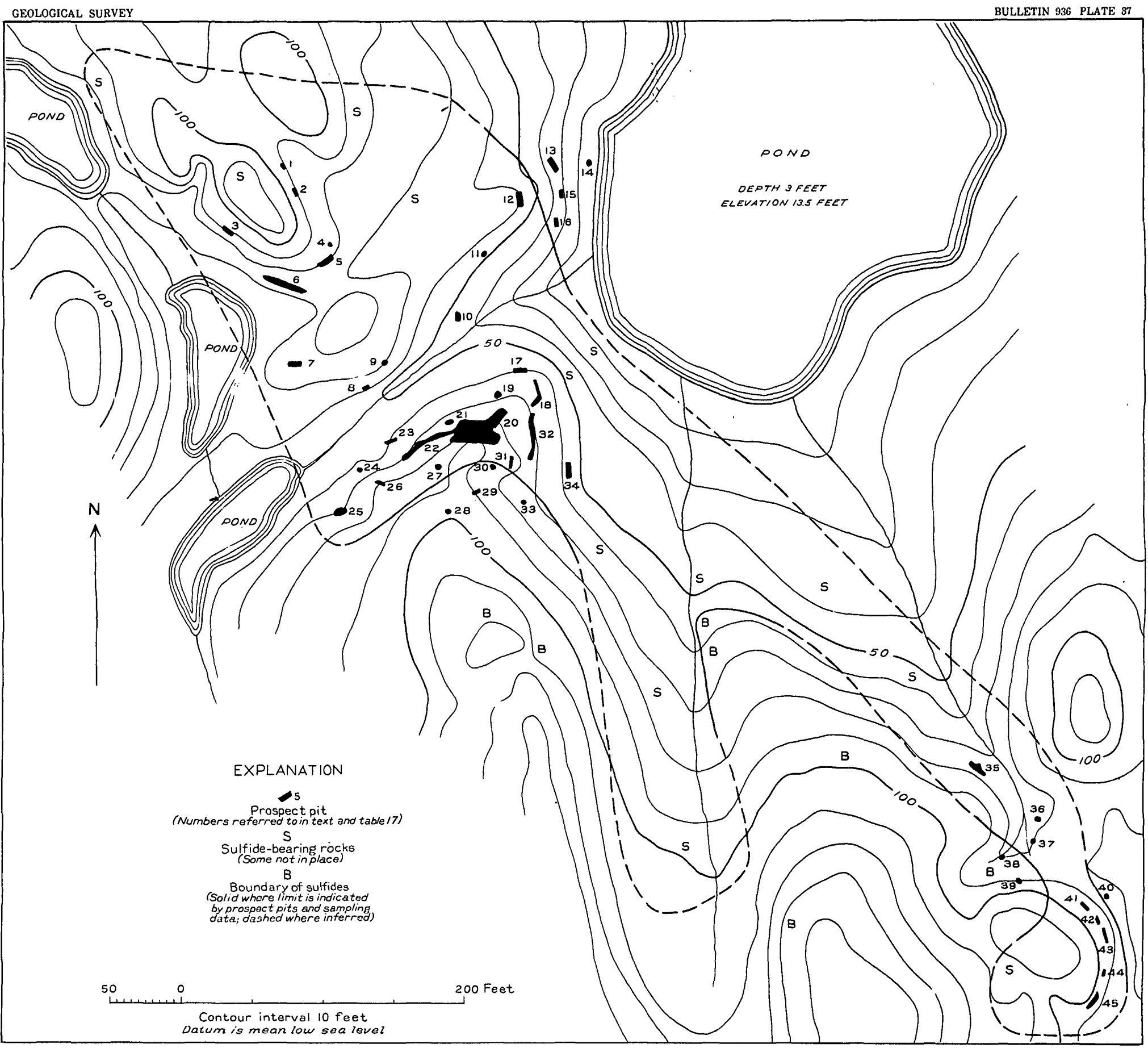

MAP SHOWING PROSPECT PITS AND TENTATIVE SURFACE OUTLINE OF THE DISSEMINATED-SULFIDE DEPOSIT, CHICHAGOF ISLANI) 
percent). Norite or amphibolite that is close to graywacke is separated from it by light-colored diorite, gabbro, or pegmatites, all of which are poor or barren in sulfides.

Results of sampling.--Each pit shown on plate 37 was sampled by the writer or his assistants by collecting chips at l-foot intervals over the exposed rock surface. Five composite samples (Nos. 26-30, table 17), representing groups of p1ts, were made by mixing portions of the powdered original samples proportionate in weight to the area represented by each sample. The rock chips were crushed and the composite samples were mixed in the laboratory of the Hirst-Chichagof mine at Kimshan Cove. The analysis of each composite sample is shown in table 17. Welghted averages of the f1ve analyses were computed as 0.16 percent of nickel and 0.08 percent of copper (sample 31, table 17). These averages represent the probable nickel-copper content of all the rock surface exposed in the 45 pits, including rock barren in sulfides. The total area sampled is 2,037 square feet.

Five pits--Nos. 4, 17, 20, 23, and 35--expose rock extraordinarily rich in sulfides. Analyses of individual samples from these pits are also given in table 17. Welghted averages of these five analyses (sample 32, table 17) representing 655 square feet are: N1ckel, 0.31 percent; and copper, 0.13 percent. The richest sample (nickel, 0.75 percent; copper, 0.30 percent), which was obtained in pit 4 , contains less copper than any of the samples from the concentrated sulfide deposits and less nickel than any of them except the sample representing about 400 square feet of the outcrop of the deposit of concentrated sulfides on Fleming Island (sample 3, table 17). 


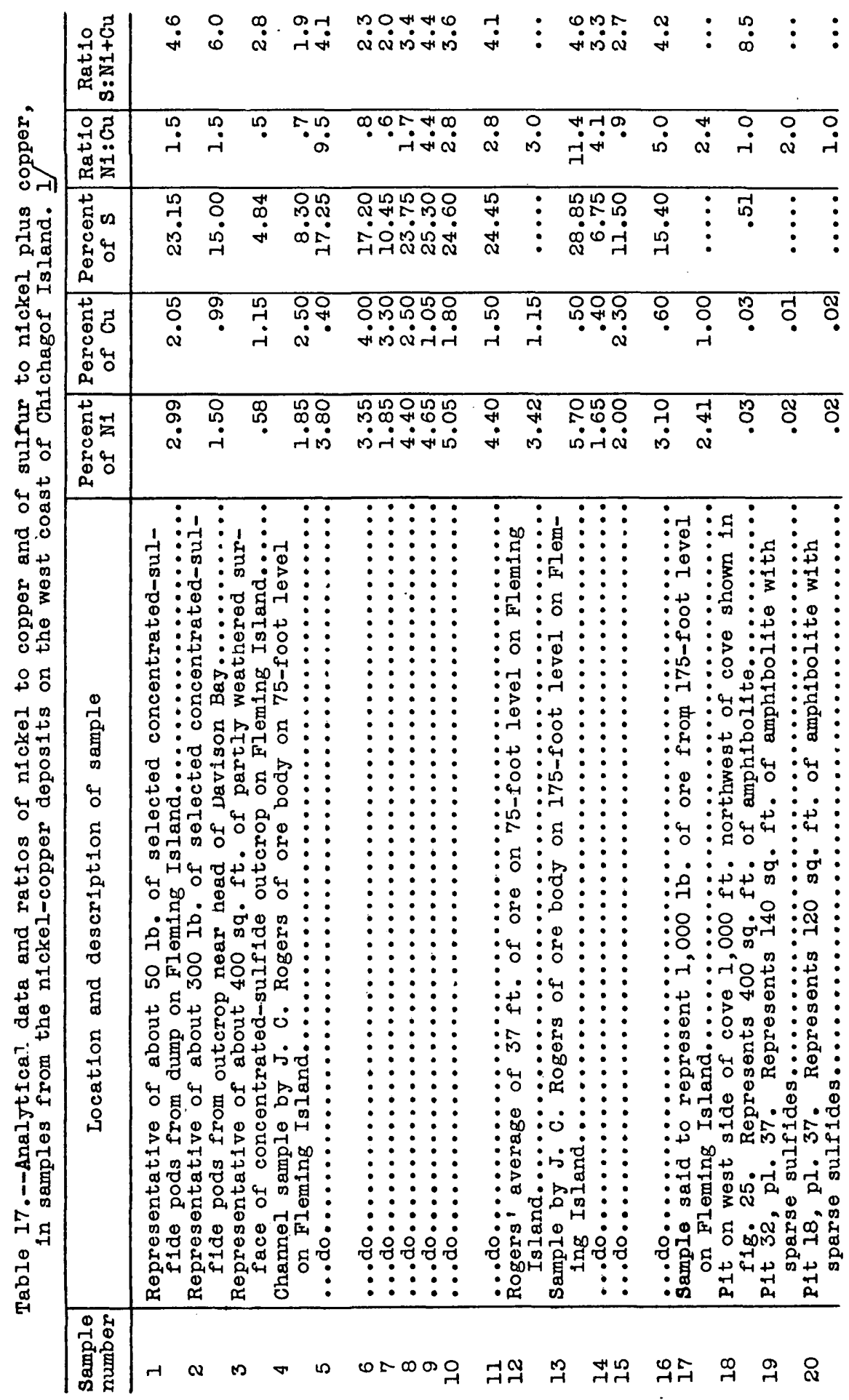




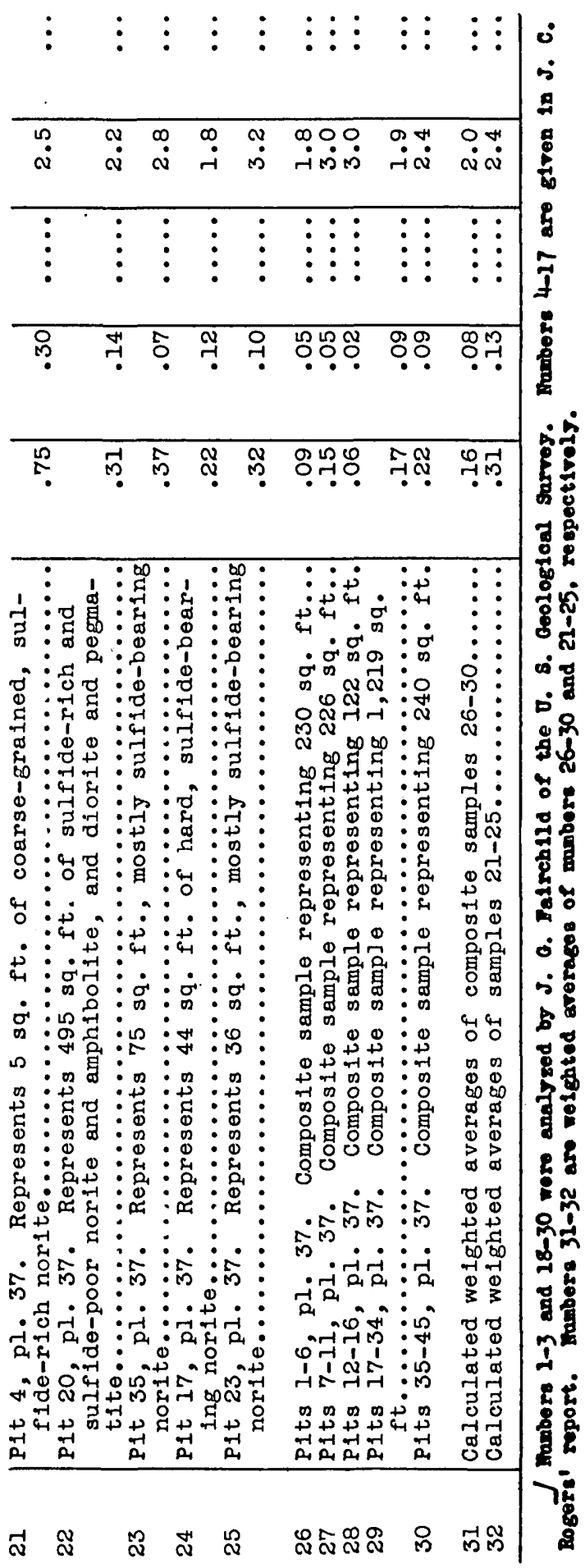




\section{Reserves}

Concentrated-sulfide deposits

Although information regarding the structure, size, and tenor of the deposit on Fleming Island is inadequate, it is assumed that the ore exposures on the surface and in the underground openings on the 75-foot and 175-foot levels are in the same ore shoot. This assumption may or may not be correct. Rogers, indeed, regards the ore indicated on the 175-foot level as belonging to a second ore body rather than as a continuation of the one exposed on the 75-foot level, and a third possibility is that each of the three exposures of ore represents a separate ore shoot.

According to the first interpretation, the ore shoot, if continuous from the surface to the 175-foot level, contains more than 10,000 short tons $11 /$ of ore with an average of about 2 percent of nickel and 1 percent of copper. According to the second interpretation, less than 8,000 tons would 110 between the surface and the 75-foot level, but there would probably be some in addition below that level. According to the third interpretation, the quantity of ore would be even smaller.

A reserve of 10,000 tons of ore with 2 percent of nickel and 1 percent of copper has a gross value $12 /$ of about $\$ 16$ per ton; It contains 200 tons of $\mathrm{nickel}$, with a gross value of about $\$ 140,000$, and 100 tons of copper, with a gross value of about $\$ 24,000$. This estimated reserve of 200 tons of nickel and 100 tons of copper is but a small fraction of 1 percent of the world's annual production of the two metals.

The deposit near the head of Davison Bay may contain a few thousand additional tons of concentrated-sulfide ore. The ore in this deposit, if it is fairly represented by the very limited

11/ 1 short ton est Imated for each 8 cablc foet of rock.

12) Wotal values are based on assumed prices of 35 cents per pound for nickeI, and 12 cents per pound for copper. Reserves are in ehort tons. 
amount of sampling, is of lower grade than that in the deposit near the shaft on Fleming Island.

\section{Disseminated-sulfide deposit}

An area of 3 acres underlain principally by rock containing disseminated sulfides has been tentatively outlined on the map forming plate 37, though the mapping will no doubt be altered in detall after further exploration is completed. This tract is densely wooded, has a relief of about 100 feet, and is well drained. For each foot of depth, this ground contains about 13,500 short tons of sulfide-bearing rock, which, on the assumption of an average tenor of 0.2 percent of nickel at 35 cents per pound and 0.1 percent of copper at 12 cents per pound, would have a gross value of about $\$ 1.64$ a ton. The assumptions as to tenor, however, are highly speculative. The welghted averages of the nickel and copper in the composite samples representing all the pits are probably a littie too low because a few small pits (pits 13-16, 28-30, 33, and 38-40), which are represented in the samples, lie outside the limits of the body. The weighted averages of the individual samples from the five pits In the body (pits 4, 17, 20,23, and 35) are obviously too high because only pits extraordinarily rich in sulfides are represented. If the deposit hes a depth of a fow hundred feet, a few million tons of disseminated-sulfide rock is indicated in the prospected area.

\section{ECONOMIC CONSIDERATIONS}

A metallurgical method of treating ore that contains pentlendite, pyrrhotite, and chalcopyrite has been successfully used for the well-known and richer deposits near Sudbury, Ontario, Canada. Recent investigations 13 concerning the metallurgical 
treatment of "low-grade nickel-copper ore" indicate that a satisfactory process for producing electrolytic nickel and copper has been developed.

Any profitable mining of the disseminated-sulfide deposit - would probably have to be done by some large-scale, low-cost method, though the concentrated-sulfide deposits might be mined by a smaller-scale, higher-cost method. The heavy precipitation of the region, the high ground-water surface, and the possibility that subsurface workings would be flooded by leakage from the sea, are factors to be considered in making any plans to mine the deposits. The proximity of the deposits to the coast offers the advantage of water transportation, but this is partly offset by the fact that the deposits cannot be closely approached by large boats and by the long distance between the deposits and markets.

The concentrated-sulfide deposits might possibly be worked with profit under present economic conditions, but at best they would yield relatively insignificant amounts of nickel and copper. The disseminated-sulfide deposit appears to be of too low grade to be profitably mined, even on a large scale, except at a very much higher price for nickel than is now obtainable.

Reed and Dorr 14/have investigated the nickel-copper deposits on Yakobi Island, 15 miles by water northeast of the depos1ts described in this paper (see fig. 22), and they report eight partly explored and four unexplored deposits of norite containing disseminated sulfide minerals. Analyses of 61 samples, representing 945 linear feet of rock, show a nickel content of from 0.03 percent to 3.60 percent. The authors estimate that in these deposits at least $6,000,000$ short tons of rock are ava1Iable that contain an average of 0.36 percent of nickel and 0.27 percent of copper, which at 35 cents a pound for nickel and 10 cents a pound for copper would have a gross value of $\$ 3.06$ a ton.

14 Beed, J. C., and Dorr, J. V. R., 2d, op. olt. 
The mining of the disseminated-sulfide deposits on both Yakob1 and Chichagof Islands presents so many similar problems that the deposits in both districts may well be considered jolntly in any plans for their commercial development. Further exploration of the known nickel-copper deposits on the west coast of Chlchagof Island is needed before any close estimates of avallable tonnage and nickel-copper tenor can be made. Further subsurface development of the body of concentrated sulfides near the shaft on Fleming Island seems justified. If a drilling program is considered for the disseminated-sulfide deposit, a preliminary magnetic survey might prove a valuable aid in outlining such a program. 